\title{
ARE ONLINE PURCHASES AFFECTED BY DEMOGRAPHIC FACTORS IN THE CZECH REPUBLIC?
}

\author{
[Jsou online nákupy v České republice ovlivněny demografickými faktory?]
}

\author{
Radka Bauerová ${ }^{1}$ \\ ${ }^{1}$ Silesian University in Opava, School of Business Administration, Univerzitní nám. 1934/3, 73340 Karvina \\ Email: bauerova@opf.slu.cz
}

\begin{abstract}
Almost 80\% of households in the Czech Republic have Internet access, which is three times higher than in 2005. This rapid development of the Internet has provided space for the development of e-tail, and online shopping has become a new form of sales. Interestingly, the development of online sales is even higher over the same period, and in $2016,43.6 \%$ of the Czech population shop online. These facts declare the importance of examining factors that can influence the purchase of consumers online, for the sake of e-tail strategic decision making. This article explores the relationship between demographic factors and online purchase using the IBM SPSS software. Secondary data from the Czech Statistical Office, which since 2005 has been monitoring online purchase in the Czech Republic, has been used to investigate. The aim of this article is to find out if demographic factors affect the online purchase. The findings reveal a statistically significant impact of age, education and economic activity on online shopping. This significance was not proven in the gender factor. The findings have practical implications in the proposed optimal demographic segmentation of online customers based on data from 2016, helping to tailor marketing e-tail activities.
\end{abstract}

Keywords: customer behaviour, demographic factors, demographic segmentation, E-marketing, online purchase, online shopping.

JEL classification: M30, M31, M39

Doručeno redakci: 28.9.2017; Recenzováno: 28.10.2017; 6.2.2018; Schváleno k publikování: 14.3.2018

\section{Introduction}

The indispensability of e-tail increases with an increasing number of online shoppers. This trend pushes on the quality of strategic decision-making by companies. This pressure is also reflected in the importance of creating the valuable e-marketing, the essence of which is the achievement of marketing objectives via the application of digital technologies (Smith and Chaffey 2005). E-marketing is much more than just the internet; it involves other technologies that enable customer relationship management, enterprise resource planning, supply chain management, text messaging, barcode scanners and digital TV (Gilmore et al. 2007). Brodie et al. (2007) argued that e-marketing is becoming an important marketing practice in most of the companies, and e-marketing's success comes from improving and supporting existing marketing practices.

Including e-marketing among marketing practices of the e-tail companies is important due to increasing online sales in the Czech Republic. Internet purchases by individuals have been increasing steadily in the Czech Republic since 2007. Almost 35\% of Czech consumers are buying goods online via the internet in 2016 (Eurostat 2017). The proportion of active online consumer buyers can increase based on its previous developments. In this context, the outcome of this study can help to identify different demographic segments of consumers. Companies can then effectively customise e-marketing tools for identified segments.

The Czech Republic ranked fifteenth in the international comparison of the number of individuals buying over the Internet in the European Union states in 2015. In the Czech Republic are only $13 \%$ of the pensioners up to 74 years of the total number of individuals who 
use online purchases (CZSO 2015). This fact can explain why the Czech Republic was ranked fifteenth in comparison with the other states of European Union. For example, compared to the United Kingdom, the country with the highest number of individuals purchasing over the Internet, there is a significant difference in the ratio of buyer pensioners. The number of pensioners who shop online is more than four times higher in the United Kingdom. However, if we look at the detailed analysis, we can find that the number of pensioners buying online increased from 2006 to 2016 nine times in the Czech Republic (CZSO 2015). The internet knowledge and skills of older people who already belong to the up to 74 years category are constantly deepening. Also, other individuals with higher technological literacy are continually adding from the previous category (CZSO 2015). This trend can cause a significant increase in online shoppers in up to 74 years category in the future. Therefore, it is important to find if age influences online purchase as well as to find, if there are others demographic factors influence online purchase in the Czech Republic. The author answers the following question in undertaking this research:

1. Which categories of the age, gender, education, and economic activity factors influence online shopping?

The aim of the article is to find out if demographic factors affect the online purchase. The literature review analyses the findings of existing online shopping articles related to the demographic factors. The following section introduces the chosen research method, used to find out the links between demographic factors and online purchase. The third part of this article describes and comments the results of the research. Tables are also used for better visualisation of results. The next part of the article summarises proven connections between demographic factors and online purchase. This section also includes the optimal demographic segmentation of online customers, helping tailor e-marketing e-tail activities. The last part contains conclusions and recommendations.

\section{Literature Review and hypotheses development}

Lee and Tan (2003) claim that customers prefer to buy online when it comes to products and services that involve a small risk of purchasing, while there is still a predominant view that customers prefer physical retailing before e-tailing. They state that customers buy online products preferably from well-known retailers or well-known brand. Customers purchase based on a functional, physical or economic need, but there are other more specific and individual shopping motives. For example, two dominant shopping motives can be identified in traditional retail. Hedonic shopping motive where customers buy for entertainment and utilitarian motive where customers shop with a goal in mind, both motives are the basic shopping motives in retail (Babin et al. 1994). However, these two motives also affect customers in the online shopping environment. Customers often buy online on a scheduled basis under the utilitarian motive, and they often shop in auctions, the hobby-type search and bargain hunting under the hedonic motive (Wolfinbarger and Gilly 2001). Empirical results from the following study also confirm hedonic and utilitarian motives in online shopping. Childers et al. (2001) claim that the hedonic and utilitarian shopping motives exist in the online environment and that unique aspect of this media (flexibility in navigation, comfort, substitutability of personal examination) create a pleasant virtual environment for customers. While the hedonic motive is the strong predictor of enjoyment attitude, the utilitarian motive is a strong predictor of the usefulness attitude (Childers et al. 2001). In contrast to these views, Pappas et al. (2017) opinion that, although hedonic and utilitarian motives are important, their existence is not a necessary condition for high purchasing intentions, because customers are influenced by their individual online shopping motives. 
The following paragraphs will examine other influences resulting from aspects of a unique online environment in online shopping. These influences affect customers' individual online shopping motives and can influence their buying attitude. For example, the perceived risk can be involved in influences mentioned. Garbarino and Strahilevitz (2004) show that perceived risk often does not match the real risk. Perceived risk should involve financial risk, privacy risk, supply risk, quality risk, social risk, health risk and after sale risk (Almatarneh 2016). However, by sharing user experience, we can then get closer to the real risk of the online shopping (Garbarino and Strahilevitz 2004).

Social influence can also have a big impact on the consumer attitudes and intention to buy products online. Empirical results from "The impact of online product recommendations on consumers' online choices" study strongly suggest that consumers are influenced by their online product choices by online recommendations. Depending on the source of advice (experts, other consumers), recommended products are purchased up to twice as often. (Senecal and Nantel 2004).

Demographic factors can be also included in factors that can influence the consumer attitude and intention to buy products online. An empirical study from Taiwan shows that the attitude towards online shopping is significantly different based on the various demographic factors (gender, age, education, occupation, income, interest, and living area) (Wu 2003). Other authors also found a relationship between buying online and demographic factors (Rodgers and Harris 2003; Rohm and Swaminathan 2004; Dennis et al. 2010; Punj 2012). In contrast to this view, other researchers disagree with the claim that the demographic factors are influencing the intention of buying online (Sorce et al. 2005; Lian and Yen 2014). For example, Lee (2010) (study from South Korea) suggests that the effects of demographic factors have moderated in the use of information technology because respondents show positive attitudes to online shopping regardless of gender, age, education and income levels. This claim suggests that influence of demographic factors in online shopping are different in some countries.

\subsection{Age as influencer of online shopping}

The situation that age affects online shopping is in general accepted in the Czech Republic. The share of different age categories of online shoppers varies across countries as already mentioned above. These differences between countries can also cause differences in the results of studies dealing with age relationships and online purchases. For example, a study conducted in the United States argue that there are no significant differences between online shopping and age category, divided age groups into a 29 -year-old or older group (age 30 or older) (Sorce et al. 2005). Empirical results from other studies support that claim. (Akhter 2012; Lee 2010).

In contrast to this view, some studies (Rohm and Swaminathan 2004; Lian and Yen 2014) support a positive relationship between age and online shopping behaviour.

Based on the mentioned studies, there are differences in age perception between countries as a factor affecting online purchasing, which may be due to the economic aspects of the countries concerned, technological and technical facilities, political aspects, levels of education provided, or cultural habits. In accordance with this assumption, the hypothesis (H1) is formulated to understand the age influence on online purchasing behaviour in the Czech Republic.

\section{H1: Younger generations shop online more often.}




\subsection{Gender as influencer of online shopping}

Following studies suggest the existence of differences in attitudes between men and women buying online. Rodgers and Harris (2003) found that women are less emotionally satisfied with e-shopping than men are. They find that women are more sceptical about completely online shopping process. They also found that women's purchase is not so positive regarding comfort as in the case of men who perceiving more confidence in online shopping. Men have in comparison with women, more positive attitudes to shopping online (Rodgers and Harris 2003). This study corresponds to the finding that the relationship between emotional trust and purchasing intent is stronger for female customers than for male customers (Zhang, Cheung and Lee 2014). The literature review shows that online customer preferences may be affected by gender in so-called social e-shopping. Dennis et al. (2010) claim that young adult women prefer websites of social e-shopping before traditional websites. Social shopping is a type of social activity and brings other new aspects that affect the hedonic motive of the online shopper.

The empirical literature on the impact of gender on online shopping is not as decisive as these studies would suggest. Results of next studies contradicted the findings above. Lian and Yen (2014) argue that the effects of sex are diminishing. They did not find any link between gender and online shopping in their research. Also, Akhter (2012) points out that regarding online spending, men and women do not differ significantly from each other, and sex is not a good predictor of spending on the Internet. In assessing the studies mentioned above, it is clear that customer attitudes are changing not only geographically but also temporally, as previously reported studies suggest the influence of gender, while current studies are sceptical.

Based on the analysis of the literature, the hypothesis $(\mathrm{H} 2)$ is formulated to understand the gender's influence on the customer behaviour in the Czech Republic.

\section{H2: Women shop online more frequently than men do.}

\subsection{Education as influencer of online shopping}

There is a research confirmed that online purchasing could be influenced by customer's education (Wu 2003). In contrast to this view, the empirical results of studies from the United States of America state that education does not influence online spending (Akhter 2012; Lee 2010). The studies differ in this area; in some countries, education has no impact on online purchasing, while in others this impact has been identified.

We think the level of education achieved can be linked to the economic situation of the customer and to the acceptance of an alternative way of purchasing products (via the Internet). Therefore, we assume that this influence may exist in the Czech Republic. Based on this statement, the hypothesis (H3) for understanding the educational influence on customer behaviour is formulated.

\section{H3: Consumers with a higher level of education shop online more often.}

\subsection{Economic activity as influencer of online shopping}

It is logical that people with higher earnings can spend more money on buying than people with lower incomes. Some studies confirm an assumption that this situation will be the same in the online environment. The studies suggest that people with higher incomes buy more often, or spend more money online than people with lower incomes (Akhter 2012; Punj 2012). Interestingly, consumers with higher incomes are attracted to timesaving features of the online buying environment largely than to money-saving aspects (Punj 2012). The different situation 
is in the case of consumers with lower incomes. They are more attractive in money-saving aspects, but they are also interested in timesaving as an important incentive to make purchases (Punj 2012).

Contrary to that view, another study suggests that incomes do not affect online shopping, and consumers have a positive attitude towards the benefits of online purchasing and its acceptance regardless of gender, age, education or income level (Lee 2010).

Since the literature has different views, we assume that income affects customer behaviour and people with higher incomes buying through online more. Based on this theory, we can analogously state that economic activity also affects online purchasing.

It can be assumed, that employed people will purchase online more than unemployed, but we are interested in finding if other categories (the woman on the parental leave, the students, the old-age pensioners and the disability pensioner's categories) has also an impact on the purchase of online products. Based on these assumptions, the hypothesis (H4) for understanding impact of economic activity on customer behaviour is formulated:

\section{H4: Consumer's economic activity affects online shopping.}

\section{Research methods}

The subject of the research is to find out if online purchases are influenced by demographic factors in the Czech Republic. Age, gender, education, and economic activity factors were chosen to examine. The One-Way ANOVA test and the Post Hoc Test (Turkey's test) were chosen as analysis methods. The analysis was done in IBM SPSS statistics software.

The findings of mentioned analysis will have practical implications in the proposed optimal demographic segmentation of online customers, helping to tailor marketing e-tail activities. The optimal demographic segmentation will focus on six online marketplaces and offer three segments of customers. The proposed segments will be set in order. The Final Cluster Centers analysis was also chosen to set up this optimal segmentation. The cluster analysis is a statistical technique that sorts observations into similar sets or group, which can have a place in strategic management's methodological tool box (Ketchen and Shook 1996).

\section{Sample}

The secondary data from the Czech Statistical Office was used to carry out the research. The size of the sample is 8961 of individuals purchasing goods online. The data used to research hypotheses were collected in the 2016 year. The CZSO survey is representative of the population of persons aged 16+ living in the Czech Republic. The population include about 8.8 million people in 2016 (CZSO 2017). The secondary data was collected in the form of a computer-assisted personal interviewing by a trained interviewer.

\section{Hypothesis testing techniques selected}

The One-Way ANOVA method was selected for testing H1, H2, H3 and H4. This method examined the variability between consumer categories and the sum of goods purchased online. It is necessary for the data to meet six conditions (measured dependence variable, consisting of two or more categorical independent variables, dependence variables should be approximately normally distributed for each category and homogeneity of variations) to use this method (Mertler and Reinhart 2016). The data can be analysed only after they fulfil the conditions. The data used for research in this article meets all above conditions. 
The next test examined if the data has a normal distribution. Normal data distribution was tested using the Kolmogorov-Smirnov Normality Test (K-S Test) also in IBM SPSS statistics. The K$\mathrm{S}$ Test confirmed that the dependent variable is approximately normally distributed for each category. The outliers were examined using a box plot together with the test.

\section{Results}

Four hypothesis was formulated to investigate the effects of demographic factors on online purchase. The results of One-way analysis of variance and the Post Hoc Test are shown in table one to seven. The following paragraphs include an analysis of results in terms of factors but also in terms of their individual categories.

\section{Age factor}

The first test examined whether age affects the purchasing behaviour of online customers. The hypothesis H1 was tested: younger generations shop online more often. The analysis showed that the p-value (Sig.) of the test is 0.002 . Since this value is less than $\alpha=0.05$, therefore pvalue $0.002<0.05$, we rejected the null hypothesis. Hypothesis 1 was accepted. The age factor affects online shopping in the Czech Republic. The result of the test is shown in table one.

Table 1: ANOVA for H1 testing

\begin{tabular}{|l|r|r|r|r|r|}
\hline & Sum of Squares & \multicolumn{1}{c|}{ df } & Mean Square & F & Sig. \\
\hline Between Groups & 273999,542 & 2 & 136999,771 & $6,909^{*}$ &, 002 \\
Within Groups & 892360,437 & 45 & 19830,232 & & \\
Total & 1166359,979 & 47 & & & \\
\hline
\end{tabular}

Source: author's calculations based on data from ČSÚ (2016)

*Significant at 0.05 level.

We know that the age categories are different in some way after rejecting the null hypothesis in One-Way ANOVA. The Post Hoc Test (Turkey's Test) was performed to determine which categories differ from the others. There is a statistically significant difference in online shopping between the category that took the 16-34 years category and the $55+$ category $(p=0.013)$, as well as in the 35-54 years category And 55+ category $(\mathrm{p}=0.004)$ as we can see in table two. However, there were no statistically significant differences between the categories that took the $16-34$ years category and $35-54$ years category $(\mathrm{p}=0.884)$. Therefore, the customers between 16 and 54 years have the same or similar online shopping habits.

Table 2: Multiple Comparisons for age category

\begin{tabular}{|ll|r|r|r|}
\hline (I) Age category & (J) Age category & Mean Difference & Std. Error & Sig. \\
\hline \multirow{2}{*}{16 - 34 years } & 35 - 54 years & $-23,56250$ & 49,78734 &, 884 \\
& 55 + years & $147,18750^{*}$ & 49,78734 &, 013 \\
\hline \multirow{2}{*}{35 - 54 years } & $16-34$ years & 23,56250 & 49,78734 &, 884 \\
& 55 + years & $170,75000^{*}$ & 49,78734 &, 004 \\
\hline \multirow{2}{*}{$55+$ years } & $16-34$ years & $-147,18750^{*}$ & 49,78734 &, 013 \\
& 35 - 54 years & $-170,75000^{*}$ & 49,78734 &, 004 \\
\hline
\end{tabular}

Source: author's calculations based on data from ČSÚ (2016)

* The mean difference is significant at the 0.05 level.

\section{Gender factor}

The second test examined whether the customer's gender has an impact on the online shopping. The hypothesis $\mathrm{H} 2$ was tested: women shop online more frequently than men do. The p-value (Sig.) of the test is 0.830 which is greater than $\alpha=0.05$ as we can see in table three. Therefore, the null hypothesis was not rejected. Gender factor is inefficient for online shopping. Thus, the 
online shopping is not influenced by gender in the Czech Republic. No differences in online shopping habits between man and woman were found. In this case, the Post Hoc test is not needed for another examining of gender factor, because the impact on the online shopping was not proved.

Table 3: ANOVA for $\mathrm{H} 2$ testing

\begin{tabular}{|l|r|r|r|r|r|}
\hline & Sum of Squares & df & Mean Square & F & Sig. \\
\hline Between Groups & 6520,563 & 1 & 6520,563 &, $048^{*}$ &, 830 \\
Within Groups & 1904582,875 & 14 & 136041,634 & & \\
Total & 1911103,438 & 15 & & & \\
\hline
\end{tabular}

Source: author's calculations based on data from ČSÚ (2016)

*Significant at 0.05 level.

\section{Education factor}

Another test examined whether education influences the purchasing behaviour of online customers. The hypothesis $\mathrm{H} 3$ was tested to find an impact of education on online shopping. The hypothesis was formulated as follows: consumers with a higher level of education shop online more often. The p-value (Sig.) of the test is 0.010 as can be seen in table four. This value is smaller than the chosen significance level $\alpha=0.05$, i.e. $p$-value $0.010<0.05$, therefore we rejected the null hypothesis. Hypothesis 3 was accepted, so the education factor affects online shopping in the Czech Republic.

Table 4: ANOVA for $\mathrm{H} 3$ testing

\begin{tabular}{|l|r|r|r|r|r|}
\hline & Sum of Squares & df & Mean Square & F & Sig. \\
\hline Between Groups & 452428,850 & 2 & 226214,425 & $6,167^{*}$ &, 010 \\
Within Groups & 623632,100 & 17 & 36684,241 & & \\
Total & 1076060,950 & 19 & & & \\
\hline
\end{tabular}

Source: author's calculations based on data from ČSÚ (2016)

*Significant at 0.05 level.

The results of ANOVA test show that education categories are different in some way. Turkey's Test was used to determine which category differs from the others. The only statistically significant difference in this analysis is the difference between the category that took the basic and secondary without A-level examination category and the secondary with A-level examination category $(\mathrm{p}=0.007)$ as table five show. The results show that there were no significant differences between the category that took the A-level category and the tertiary category $(\mathrm{p}=0.301)$, as well as between tertiary category and secondary with A-Level category $(\mathrm{p}=0.236)$.

Table 5: Multiple Comparisons for education category

\begin{tabular}{|c|c|c|c|c|}
\hline (I) Education & (J) Education & $\begin{array}{c}\text { Mean } \\
\text { Difference }\end{array}$ & Std. Error & Sig. \\
\hline $\begin{array}{l}\text { Basic and secondary without } \\
\text { A-level examination }\end{array}$ & $\begin{array}{l}\text { Secondary with A-level examination } \\
\text { Tertiary }\end{array}$ & $\begin{array}{r}-366,10000^{*} \\
-160,90000\end{array}$ & $\begin{array}{l}104,90602 \\
104,90602\end{array}$ & $\begin{array}{l}, 007 \\
, 301\end{array}$ \\
\hline $\begin{array}{l}\text { Secondary with A-level } \\
\text { examination }\end{array}$ & $\begin{array}{l}\text { Basic and secondary without A-level } \\
\text { examination } \\
\text { Tertiary }\end{array}$ & $\begin{array}{r}366,10000^{*} \\
205,20000 \\
\end{array}$ & $\begin{array}{l}104,90602 \\
121,13503 \\
\end{array}$ & $\begin{array}{l}, 007 \\
236 \\
\end{array}$ \\
\hline Tertiary & $\begin{array}{l}\text { Basic and secondary without A-level } \\
\text { examination } \\
\text { Secondary with A-level examination }\end{array}$ & $\begin{array}{r}160,90000 \\
-205,20000\end{array}$ & $\begin{array}{l}104,90602 \\
121,13503\end{array}$ & $\begin{array}{l}, 301 \\
, 236\end{array}$ \\
\hline
\end{tabular}

Source: author's calculations based on data from ČSÚ (2016)

* The mean difference is significant at the 0.05 level. 


\section{Economic activity factor}

The last One-Way ANOVA test examined whether the economic activity has an impact on the online customer purchasing behaviour. The hypothesis $\mathrm{H} 4$ was tested: consumer's economic activity affects online shopping. The P-value of the test is 0.000 as table six shows. Since the $\mathrm{P}$-value of test is $0.000<\alpha=0.05$, we rejected the null hypothesis. Hypothesis 4 was accepted, so economic activity factor affects online shopping in the Czech Republic.

Table 6: ANOVA for $\mathrm{H} 4$ testing

\begin{tabular}{|l|r|r|r|r|r|}
\hline & Sum of Squares & \multicolumn{1}{c|}{ df } & Mean Square & F & Sig. \\
\hline Between Groups & 3539108,438 & 5 & 707821,688 & $18,689^{*}$ &, 000 \\
Within Groups & 1590716,875 & 42 & 37874,211 & & \\
Total & 5129825,313 & 47 & & & \\
\hline
\end{tabular}

Source: author's calculations based on data from ČSÚ (2016)

*Significant at 0.05 level.

The results of the ANOVA test show that economic activity categories are different in some way. Turkey's Test found statistically significant $(\mathrm{p}=0.000)$ difference between the category that took the employed category and the unemployed, the woman on the parental leave, the students, the old-age pensioners and the disability pensioner's categories as table seven shows.

Table 7: Multiple Comparisons for economic activity category

\begin{tabular}{|c|c|c|c|c|}
\hline (I) Economic activity & (J) Economic activity & Mean Difference & Std. Error & Sig. \\
\hline Employed & $\begin{array}{l}\text { Unemployed } \\
\text { Woman on parental leave } \\
\text { Students } \\
\text { Old - age pensioners } \\
\text { Disability pensioners }\end{array}$ & $\begin{array}{l}761,25000^{*} \\
687,87500^{*} \\
682,50000^{*} \\
720,50000^{*} \\
765,50000^{*}\end{array}$ & $\begin{array}{l}97,30649 \\
97,30649 \\
97,30649 \\
97,30649 \\
97,30649\end{array}$ & $\begin{array}{l}, 000 \\
, 000 \\
, 000 \\
, 000 \\
, 000\end{array}$ \\
\hline Unemployed & $\begin{array}{l}\text { Employed } \\
\text { Woman on parental leave } \\
\text { Students } \\
\text { Old - age pensioners } \\
\text { Disability pensioners }\end{array}$ & $\begin{array}{r}-761,25000^{*} \\
-73,375000 \\
-78,75000 \\
-40,75000 \\
4,25000 \\
\end{array}$ & $\begin{array}{l}97,30649 \\
97,30649 \\
97,30649 \\
97,30649 \\
97,30649 \\
\end{array}$ & $\begin{array}{r}, 000 \\
, 974 \\
, 964 \\
, 998 \\
1,000 \\
\end{array}$ \\
\hline Woman on parental leave & $\begin{array}{l}\text { Employed } \\
\text { Unemployed } \\
\text { Students } \\
\text { Old - age pensioners } \\
\text { Disability pensioners }\end{array}$ & $\begin{array}{r}-687,87500^{*} \\
73,37500 \\
-5,37500 \\
32,62500 \\
77,62500 \\
\end{array}$ & $\begin{array}{l}97,30649 \\
97,30649 \\
97,30649 \\
97,30649 \\
97,30649 \\
\end{array}$ & $\begin{array}{r}, 000 \\
, 974 \\
1,000 \\
, 999 \\
, 966 \\
\end{array}$ \\
\hline Students & $\begin{array}{l}\text { Employed } \\
\text { Unemployed } \\
\text { Woman on parental leave } \\
\text { Old - age pensioners } \\
\text { Disability pensioners }\end{array}$ & $\begin{array}{r}-662,50000^{*} \\
78,75000 \\
5,37500 \\
38,00000 \\
83,00000 \\
\end{array}$ & $\begin{array}{l}97,30649 \\
97,30649 \\
97,30649 \\
97,30649 \\
97,30649 \\
\end{array}$ & $\begin{array}{r}, 000 \\
, 964 \\
1,000 \\
, 999 \\
, 955 \\
\end{array}$ \\
\hline Old - age pensioners & $\begin{array}{l}\text { Employed } \\
\text { Unemployed } \\
\text { Woman on parental leave } \\
\text { Students } \\
\text { Disability pensioners }\end{array}$ & $\begin{array}{r}-720,50000^{*} \\
40,75000 \\
-32,62500 \\
-38,00000 \\
45,00000 \\
\end{array}$ & $\begin{array}{l}97,30649 \\
97,30649 \\
97,30649 \\
97,30649 \\
97,30649 \\
\end{array}$ & $\begin{array}{l}, 000 \\
, 998 \\
, 999 \\
, 999 \\
, 997 \\
\end{array}$ \\
\hline Disability pensioners & $\begin{array}{l}\text { Employed } \\
\text { Unemployed } \\
\text { Woman on parental leave } \\
\text { Students } \\
\text { Old - age pensioners }\end{array}$ & $\begin{array}{r}-765,50000^{*} \\
4,25000 \\
-77,62500 \\
-83,00000 \\
-45,00000\end{array}$ & $\begin{array}{l}97,30649 \\
97,30649 \\
97,30649 \\
97,30649 \\
97,30649\end{array}$ & $\begin{array}{r}, 000 \\
1,000 \\
, 966 \\
, 955 \\
, 997\end{array}$ \\
\hline
\end{tabular}

Source: author's calculations based on data from ČSÚ (2016)

* The mean difference is significant at the 0.05 level. 
The results show that there were no significant differences between the unemployed and the woman on the parental leave categories $(\mathrm{p}=0.974)$, the unemployed and the students categories $(p=0.964)$, the unemployed and the old-age pensioners categories $(p=0.998)$ and between the unemployed and the disability pensioners categories $(p=1)$. All of the categories have very high significance compared to each other.

\section{Discussion}

In particular, the findings relating to an impact of age, education and economic activity on online shopping confirm previous researchers' findings (Wu 2003; Rohm and Swaminathan 2004; Akhter 2012; Punj 2012; Lian and Yen 2014). On the other hand, the findings show that the gender factor does not affect the online shopping. This result is in contradiction with some previous studies that claim that gender affects online purchase (Rodgers and Harris 2003; Zhang, Cheung and Lee 2014).

This study found that younger generations shop online more often $(F=6.909, p=0.002)$. A Post Hoc Turkey test revealed that online shopping was statistically significantly higher after taking the 16-34 years and 35-54 years categories compared to the 55+ category. There was no statistically significant difference between the 16-34 years and 35-54 years categories $(\mathrm{p}=$ 0.884). Therefore, age factor affects online shopping. The accepted hypothesis also confirmed the reflection indicated in the introduction of the paper. Consumers' age can cause the ranked of the Czech Republic in the international comparison of the EU countries.

Consumers with higher level of education shop online more often $(F=6.167, p=0.010)$. The Post Hoc Turkey test showed that online shopping was statistically significantly higher after taking the secondary with A-level examination category compared to the basic and secondary without A-level examination category. There were no significant differences between the categories that took the A-level category and the tertiary category $(p=0.301)$, as well as between tertiary category and secondary with A-Level category $(p=0.236)$. Education factor affects online shopping in the Czech Republic.

Consumer's economic activity affects online shopping $(\mathrm{F}=18.689, \mathrm{p}=0.000)$. The Post Hoc Turkey test showed that online shopping was statistically significantly higher after taking the employed category compared to all other categories $(\mathrm{p}$ 's $=0.000)$. There was no statistically significant difference between other categories (unemployed, women on parental leave, students, old-age pensioners, disability pensioners), all of which had significant between 0.955 and 1. Categories with very high significance (Sig. $>0,05$ ) do not have a statistically significant impact on online shopping. Economic activity affects online shopping.

\section{Managerial implications}

This study confirms that age, education, and economic activity are the demographic factors that affect online shopping in the Czech Republic. Based on the One-Way ANOVA, the Post Hoc Test and Final Cluster Centers analysis results, it was possible to propose an optimal online customer's demographic segmentation (OCDS) for the online market. The optimal OCDS can help to tailor e-marketing activities for individual product categories on the online market. The OCDS based on secondary data collected in the 2016 year is shown in table eight. Three segments have been set for six product categories of the online marketplace. The proposed segments are set in order. Segment 1 is the largest segment of the online market. Segment 2 is a smaller segment and segment 3 is the smallest segment of the online market. For example, consumers which are employment, their age is between 45 and 54 years and have a secondary education without A-level, are the most potential customers of companies selling grocery 
online. However, the organisation can choose only those online market segments that are in the interest of its marketing and product strategy.

Table 8: Demographic segmentation of the online market

\begin{tabular}{|c|c|c|c|}
\hline Online market & Segment 1 & Segment 2 & Segment 3 \\
\hline $\begin{array}{l}\text { Clothes, footwear, } \\
\text { fashion accessories and } \\
\text { sporting goods }\end{array}$ & $\begin{array}{c}35-44 \text { years, } \\
\text { secondary with A-level, } \\
\text { employment }\end{array}$ & $\begin{array}{c}16-24 \text { years, tertiary, } \\
\text { students }\end{array}$ & $\begin{array}{l}25-34 \text { years, } \\
\text { secondary without A- } \\
\text { level, women on } \\
\text { parental leave }\end{array}$ \\
\hline $\begin{array}{l}\text { Grocery beverages, } \\
\text { drugstores, medicines and } \\
\text { vitamins }\end{array}$ & $\begin{array}{c}45-54 \text { years, } \\
\text { secondary without A- } \\
\text { level, employment }\end{array}$ & $\begin{array}{c}35-44 \text { years, tertiary, } \\
\text { women on parental } \\
\text { leave }\end{array}$ & $\begin{array}{c}25-34 \text { years, } \\
\text { secondary with A-level } \\
\text { and higher education, } \\
\text { students }\end{array}$ \\
\hline $\begin{array}{l}\text { Electronics, computer } \\
\text { hardware and software }\end{array}$ & $\begin{array}{c}25-34 \text { years, } \\
\text { secondary with A-level } \\
\text { and higher education, } \\
\text { employment }\end{array}$ & $\begin{array}{c}35-44 \text { years, tertiary, } \\
\text { employment }\end{array}$ & $\begin{array}{l}16-24 \text { years, } \\
\text { secondary without A- } \\
\text { level, students }\end{array}$ \\
\hline $\begin{array}{l}\text { Household/apartment } \\
\text { equipment and electrical } \\
\text { appliances }\end{array}$ & $\begin{array}{c}35-44 \text { years, } \\
\text { secondary with A-level } \\
\text { and higher education, } \\
\text { employment }\end{array}$ & $\begin{array}{c}45-54 \text { years, tertiary } \\
\text { employment }\end{array}$ & $\begin{array}{c}55 \text { - } 64 \text { years, secondary } \\
\text { without A-level, old- } \\
\text { age pensioners }\end{array}$ \\
\hline $\begin{array}{l}\text { Film, music, books, } \\
\text { newspapers, magazines } \\
\text { and e-learning materials }\end{array}$ & $\begin{array}{c}25-34 \text { years, } \\
\text { secondary with A-level } \\
\text { and higher education, } \\
\text { employment }\end{array}$ & $\begin{array}{c}35-44 \text { years, tertiary, a } \\
\text { woman on parental } \\
\text { leave }\end{array}$ & $\begin{array}{l}16-24 \text { years, } \\
\text { secondary without A- } \\
\text { level, students }\end{array}$ \\
\hline Toys and board games & $\begin{array}{l}35 \text { - } 44 \text { years, secondary } \\
\text { with A-level and higher } \\
\text { education, employment }\end{array}$ & $\begin{array}{c}25-34 \text { years, tertiary, a } \\
\text { woman on parental } \\
\text { leave }\end{array}$ & $\begin{array}{c}55-64 \text { years, } \\
\text { secondary without A- } \\
\text { level, old-age } \\
\text { pensioners }\end{array}$ \\
\hline
\end{tabular}

Source: author's segmentation based on data from ČSÚ (2016)

\section{Conclusion}

The relation between consumer product categories preference and consumer's demographic characteristic can be a base for marketers to improve and fit their decisions toward e-marketing activities. This article aim was to find out if demographic factors affect the online purchase. The research examined a secondary data from the Czech Statistical Office which monitoring online purchase in the Czech Republic since 2005. The findings of a One-way analysis of variance confirmed three of four hypothesis tested as shown table one to seven. This study provided evidence that demographic factors affected online purchasing in the Czech Republic. Based on the research, it is possible to answer the questions. Age, education, and economic activity have a significant impact on online shopping, whereas, in the gender factor, this significance was not proven. The research found that younger generations shop online more often than generation $55+$ do. The research also confirmed that consumer's behaviour is linked to the level of education an economic activity. This study found, that consumers with a higher level of education shop online more often than consumers with basic and secondary without Alevel examination level of education do.

The study contains practical benefits in the form of the optimal online customer's demographic segmentation (OCDS) usable in e-tail or hybrid companies. OCDS can help to tailor emarketing activities for the online market. The online market in this study was divided into six product categories. It is important to target those segments, which can be the most profitable for a company. Therefore, the segments in OCDS are set in order by their size. Three demographic segments for each online product categories (proposed by the One-Way ANOVA, 
the Post Hoc Test and the Final Cluster Centers analysis results) was created in OCDS. Marketing managers can effectively customise e-marketing tools for identified segments of online shopping consumers by using OCDS. For example, it was found that consumers which are employment, their age is between 45 and 54 years and have a secondary education without A-level, are the most potential customers of companies selling grocery online.

\section{Acknowledgement}

This research was financially supported by the Student grant competition project SGS/7/2017: "Acceptance of technology from the perspective of marketing tools."

\section{References}

[1] AKHTER, S. H., 2012. Who spends more online? The influence of time, usage variety, and privacy concern on online spending. Journal of Retailing and Consumer Services, vol. 19 , issue 1, pp. 109-115.

[2] ALMATARNEH, N., 2016. Online Shopping Risks and Effect on Consumers Purchasing Behavior. International Journal of Online Marketing Research, vol. 2, issue. 1, pp. 62-69.

[3] BABIN, B. J., W. R. DARDEN and M. GRIFFIN, 1994. Work and/or Fun: Measuring Hedonic and Utilitarian Shopping Value. Journal of Consumer Research, vol. 20, issue 4, pp. 644-656.

[4] BRODIE, R. J., H. WINKLHOFER, N. E. COVIELLO and W. J. JOHNSTON, 2007. Is e-marketing coming of age? An examination of the penetration of e-marketing and firm performance. Journal of Interactive Marketing, vol. 21, issue 1, pp. 2-21.

[5] Czech statistical office. ČSÚ Information leaflet 2015. Information technologies in houselohlds and between individuals. [online]. [2017-08-09]. Available from: https://www.czso.cz/documents/10180/23180875/letak_jednotlivci.pdf/f499cc8b-82154fac-a33c-b1fc067dccd2?version=1.1

[6] Czech statistical office. ČSÚ Methodology of the survey 2017. [online]. [2017-08-09]. Available from: https://www.czso.cz/documents/10180/50104893/06200416m.pdf/2cfeacfa-c88b-416e-a4a6-6f8d264b0919?version=1.2

[7] DENNIS, C., A. MORGAN, L. T. WRIGHT and C. JAYAWARDHENA, 2010. The influences of social e-shopping in enhancing young women's online shopping behaviour. Journal of Customer Behaviour, vol. 9, issue 2, pp. 151-174.

[8] Eurostat. Products Databasets 2017. Internet purchases by individuals. [online]. [201708-14]. Available

from: http://appsso.eurostat.ec.europa.eu/nui/submitViewTableAction.do

[9] GARBARINO, E. and M. STRAHILEVITZ, 2004. Gender differences in the perceived risk of buying online and the effects of receiving a site recommendation. Journal of Business Research, Marketing on the web - behavioral, strategy and practices and public policy, vol. 57, issue 7, pp. 768-775.

[10] GILMORE A., D. GALLAGHER and S. HENRY, 2007. E-marketing and SMEs: operational lessons for the future. European Business Review, vol. 19, issue 3, pp. 234247.

[11] CHAFFEY D. and P. R. SMITH, 2008. EMarketing eXcellence: planning and optimizing your digital marketing. 3rd Ed. Amsterdam: Butterworth-Heinemann. 
[12] CHILDERS, T. L., C. L. CARR, J. PECK, and S. CARSON, 2001. Hedonic and utilitarian motivations for online retail shopping behavior. Journal of Retailing, vol. 77, issue 4, pp. $511-535$.

[13] KETCHEN, D. J. and C. L. SHOOK, 1996. The Application of Cluster Analysis in Strategic Management Research: An Analysis and Critique. Strategic Management Journal, vol. 17, issue 6, pp. 441-458.

[14] LEE, J., 2010. The Roles of Demographics on the Perceptions of Electronic Commerce Adoption. Academy of Marketing Studies Journal, vol. 14, issue 1, pp. 71-89.

[15] LEE, K. S. and S. J. TAN, 2003. E-retailing versus physical retailing: A theoretical model and empirical test of consumer choice. Journal of Business Research, vol. 56, issue 11, pp. 877-885.

[16] LIAN, J.-W. and D. C. YEN, 2014. Online shopping drivers and barriers for older adults: Age and gender differences. Computers in Human Behavior, vol. 37, isuue 1, pp. 133-143.

[17] MERTLER, C. A. and R. V. REINHART, 2016. Advanced and Multivariate Statistical Methods: Practical Application and Interpretation. 6th Ed. Oxford: Routledge.

[18] PAPPAS, I. O., P. E. KOUROUTHANASSIS, M. N. GIANNAKOS and G. LEKAKOS, 2017. The interplay of online shopping motivations and experiential factors on personalized e-commerce: A complexity theory approach. Telematics and Informatics, vol. 34 , issue 5 , pp. $730-742$.

[19] PUNJ, G., 2012. Income effects on relative importance of two online purchase goals: Saving time versus saving money? Journal of Business Research, vol. 65, issue 5, pp. 634640.

[20] RODGERS, S. and M. A. HARRIS, 2003. Gender and E-Commerce: An Exploratory Study. Journal of Advertising Research, vol. 43, issue 3, pp. 322-329.

[21] ROHM, A. J. and V. SWAMINATHAN, 2004. A typology of online shoppers based on shopping motivations. Journal of Business Research, vol. 57, issue 7, pp. 748-757.

[22] SENECAL, S. and J. NANTEL, 2004. The influence of online product recommendations on consumers' online choices. Journal of Retailing, vol. 80, issue 2, pp. 159-169.

[23] SORCE P., V. PEROTTI and S. WIDRICK, 2005. Attitude and age differences in online buying. International Journal of Retail \& Distribution Management, vol. 33, issue 2, pp. 122-132.

[24] WOLFINBARGER, M. and M. C. GILLY, 2001. Shopping Online for Freedom, Control, and Fun. California Management Review, vol. 43, issue 2, pp. 34-55.

[25] WU, S., 2003. The relationship between consumer characteristics and attitude toward online shopping. Marketing Intelligence \& Plan, vol. 21, issue 1, pp. 37-44.

[26] ZHANG, K. Z. K., C. M. K. CHEUNG and M. K. O. LEE, 2014. Examining the moderating effect of inconsistent reviews and its gender differences on consumers' online shopping decision. International Journal of Information Management, vol. 34, issue 2, pp. 89-98. 